This item was submitted to Loughborough's Research Repository by the author.

Items in Figshare are protected by copyright, with all rights reserved, unless otherwise indicated.

\title{
A narrative inquiry into the experience of negotiating the dominant stories of physical education: living, telling, re-telling, and re-living
}

PLEASE CITE THE PUBLISHED VERSION

http://dx.doi.org/10.1080/13573322.2015.1108300

\section{PUBLISHER}

Routledge (@ Taylor \& Francis)

\section{VERSION}

AM (Accepted Manuscript)

\section{PUBLISHER STATEMENT}

This work is made available according to the conditions of the Creative Commons Attribution-NonCommercialNoDerivatives 4.0 International (CC BY-NC-ND 4.0) licence. Full details of this licence are available at: https://creativecommons.org/licenses/by-nc-nd/4.0/

\section{LICENCE}

CC BY-NC-ND 4.0

\section{REPOSITORY RECORD}

Casey, Ashley, and Lee Schaefer. 2019. "A Narrative Inquiry into the Experience of Negotiating the Dominant Stories of Physical Education: Living, Telling, Re-telling, and Re-living". figshare. https://hdl.handle.net/2134/19545. 
A Narrative Inquiry into the experience of negotiating the dominant stories of physical education: Living, telling, re-telling, and re-living

Ashley Casey $^{12}$ and Lee Schaefer ${ }^{3}$

${ }^{1}$ School of Sport, Exercise and Health Sciences, Loughborough University

${ }^{2}$ Department of Physical Education and Sports Sciences, University of Limerick

${ }^{3}$ Faculty of Education, University of Regina

\section{Corresponding Author}

Dr Ashley Casey

ZZ1.08 - Matthew Arnold Building

School of Sport, Exercise and Health Sciences,

Loughborough University,

Loughborough,

LE11 3TU,

UK.

Email: A.J.B.Casey@lboro.ac.uk 


\begin{abstract}
This paper explores the tensions that surfaced as a teacher of physical education shifted his ‘stories to live by’ (Clandinin and Connelly, 1999) around physical education. The tensions became explicit when his shifting 'stories to live by’ bumped against dominant narratives of physical education that shaped his professional knowledge landscape. Our inquiry is framed by Dewey’s pragmatic ontology (1938) and Clandinin and Connelly's (1995) narrative conception of experience as the living and telling, re-telling and re-living, of stories of experience. We also draw on Connelly and Clandinin’s (1999) narrative conception of identity as ‘stories to live by' which is an embodied, fluid and context-dependent view of identity as situated at the interface between personal practical knowledge and professional knowledge landscapes.
\end{abstract}

We begin with situating this work within the broader spectrum of narrative research. We then describe the relational processes of re-telling the stories through narrative inquiry (Author 1 and 2) and finally explore the re-living of these stories in order to show the tensions that surfaced as Author 1's 'stories to live by’ shifted. We engage in the narrative inquiry process of re-telling using the three-dimensional narrative inquiry space (with dimensions of place, sociality, temporality), to show tensions and shifting identities. We conceptualize these tensions as moments of autobiographical revisions (Carr, 1986). These revisions are seen as a part of a person’s struggle for narrative coherence; a struggle to compose a life in the professional knowledge landscape that is meaningful to each individual. In these moments of autobiographical revision we show the reflexive relationship between living, telling, re-telling and reliving of stories. We end by considering what we have learned about our own stories 
to live by through this process and theoretically and practically suggest ways other teacher educators and physical educators might benefit from engaging in narrative inquiry work.

Key Words: Narrative, Teacher-as-Researcher, Socialisation, Teacher Change, Curriculum Change 


\section{A Narrative Inquiry into the experience of negotiating the dominant stories of physical education: Living, telling, re-telling, and re-living}

“ Experience thus reaches down into nature; it has depth. It also had breadth and to an indefinitely elastic extent. It stretches”

(Dewey, 1958, p. 4a)

"The answer to the question, why narrative? Is, because experience”

(Clandinin \& Connelly, 2000, p. 50)

In this paper we explore the tensions that surfaced as Ashley shifted his 'stories to live by’ (Clandinin and Connelly, 1999) around physical education. We begin with quotations from both Dewey and Clandinin and Connelly, to bring attention to our ontological commitment to experience. Our inquiry is framed by Dewey’s pragmatic ontology (1938) and Clandinin and Connelly’s (1995) narrative conception of experience as the living, telling, re-telling and re-living of stories of experience. We also draw on Connelly and Clandinin’s (1999) narrative conception of identity as 'stories to live by' which is an embodied, fluid and context-dependent view of identity as situated at the interface between personal practical knowledge and professional knowledge landscapes.

While narrative research has moved in from the margins (Clandinin, 2013), the words narrative and research together still seem to breed resistance from those engaged in more dominant research paradigms. While this resistance takes on different feels in different contexts, it seems that critiques point out the absence of rigor, the lack of theory, and the deficiency of generalizable findings. Like many narrative researchers, Dowling, Garrett, Hunter and Wrench (2013) take up these 
critiques and illustrate the plethora of narrative research that has taken place in, and added to, the knowledge base of physical education. Like Clandinin and Rosiek (2007) we feel that often resistance comes from a lack of knowledge and at times confusion, surrounding narrative work.

While paradigm wars are nothing new, and we can often agree to disagree with critiques of narrative work, it is partly our fault as narrative researchers for not making our ontological and epistemological commitments clear (Clandinin, 2013). When we start to look at Dowling et al.’s (2013) literature review of narrative research in physical education we begin to see the messiness that comes with narrative work. This messiness arises, it seems, both from the multiple forms of narrative research that exist and the unique context of each individual's experience. While this could be seen as a detriment, like others we admire the variety of ontological and epistemological commitments taken up by those undertaking narrative research.

While this is not the scope of this particular paper, we find it necessary to point out the messiness that comes from doing narrative work. We begin the paper this way because, like Clandinin (2013), we see it as part of our responsibility as narrative inquirers to clearly lay out our ontological and epistemological commitments to attempt to not only justify our work personally, socially and practically, but to clearly define how we are using narrative inquiry in this paper.

\section{Narrative research in Physical Education}

Based on Dowling et al.'s (2013) review of literature it becomes clear that the work we are doing in this particular paper is different than past work done around physical education. Much of the work described in their literature review begins with epistemological commitments. What we want to make clear is that our particular 
study did not begin from an epistemological commitment to a knowledge frame. Using Clandinin and Connelly’s (1990, 2000) and Clandinin’s (2013) notion of narrative inquiry, which stems from Dewey’s theory of experience that includes continuity and interaction, we begin with an ontological commitment to experience which in turn shapes the entire study, including the transactional nature of the process and the findings.

Clandinin (2013) calls for narrative inquirers to justify their work personally, practically and socially, or theoretically. Given that we are former physical education teachers and current PETE academics who focus on physical education pedagogy, the bumping that arose for Ashley as his stories of physical education collided with the grand narratives on the professional knowledge landscape created an important phenomenon for inquiry. Therefore, since both Authors have moved from teacher education programmes to teaching in schools, and have now become PETE educators, we resonated strongly with this bumping.

Practically, we see this work as more than structured reflective practice. "We write to learn” (Clandinin, 2013, p. 206) and this inquiry and writing allows us to think hard not only about how we negotiated the 'bumping places', but also how we might begin to prepare our pre service PETE teachers for the bumping that will no doubt ensue as their imagined stories of physical education bump with the grand narratives on the professional knowledge landscapes (Rossi, lisahunter, Christensen \& Macdonald, 2015; Schaefer \& Clandinin, 2011). We also see narrative inquiry, done in collaboration between two PETE teacher educators, as an approach that enables us to think in more structured ways about our practice, which we hope may provide resonance for others in their contexts and in their own PETE programmes. 
Socially or theoretically we see this work as adding to the little work that has been done in physical education using Clandinin and Connelly’s (1990, 2000) notion of narrative inquiry. While this paper may begin with different philosophical implications, we see it as adding to interpretative work done in physical education around teacher reflection (Tsangaridou \& O’Sullivan, 1997), teacher action (Tsangaridou \& O’Sullivan, 2003), teacher knowledge (McCaughtry, 2004; Rovengo, Chen, \& Todorovich, 2003), teacher change (Kirk \& Macdonald, 2001) and teachers’ lives (Armour \& Jones, 1998; O’Sullivan, 1994;)

Along with adding to physical education, we also see this work as contributing to the field of narrative inquiry in ways that illustrate teacher knowledge (Clandinin, Schaefer, \& Downey, 2014), narrative inquiry as pedagogy (Schaefer, 2013), negotiating borderland spaces by writing counter stories, and by illustrating the process of what it is to do narrative inquiry work in relational collaboration.

\section{Teachers not as outsiders but as curriculum makers}

In their literature reviews of school reform and teacher change, Connelly and Clandinin (1998) found that students and teachers are often situated outside of school reform and teacher change initiatives. "Both historically and currently, teachers have been viewed as in a conduit, their purposes flowing down to them from others” (Connelly \& Clandinin, 1994, p. 147). As others decide what is most important in schools (others being administrators, curriculum planners, government etc.) the purpose of the teacher is not decided by the teachers themselves but is instead passed down to them from this conduit for them to deliver. Consequently, teachers are positioned as untrustworthy, non-knowledge holders in terms of curriculum reform. This lack of trust means that educational reform is often 'teacher proofed' 
(Macdonald, 2003) inasmuch as the knowledge required to deliver the reform is now 'pre-packaged' (Darling-Hammond, 2010, p. 41) as discrete activities, or curriculum.

In contrast, and in developing a view of teachers as curriculum planners, Connelly and Clandinin (1988) investigated the relationships between theory and practice. They positioned educational theorists in universities and educational practitioners in schools in very different places on a professional knowledge landscape and further posited that practitioners do education and theorists think about it, and both place different value upon it. The differences Clandinin and Connelly (1988) saw between theorists and practitioners were highlighted in the way that theorists and practitioners thought about the curriculum: Academics think in terms of models, samples, subjectivity, and experiments while teachers think about the nuances (the seen and unseen, obdurate, and chthonic) that allow the curriculum as a process to operate over time.

It is not only that we have different levels of thought about the same thing, one practical and one theoretical, but also that the thing itself is different, one taking the form of ideas and the other the form of actions.

(Connelly \& Clandinin, 1988, p. 87)

In our inquiries into Ashley’s stories of experience we see, like many others, (c.f. Clandinin \& Connelly, 2000; Connelly \& Clandinin, 1998; Huber, Murphy \& Clandinin, 2011) that separating theory and practice reduces the complexities, nuances and contextual nature of curriculum which is ingrained with practice. Clandinin and Connelly’s (1998) notions of curriculum-making as a life-making process help us to see that the curriculum is more than a written document and is better understood as a complex living process in the lives of teachers and students. In this particular paper we pick up on Clandinin and Connelly's work, and conceptualize curriculum in a narrative way i.e. curriculum-making as a life-making process, and in 
a way that sees the curriculum as always in the midst rather than as a fixed entity. Connelly and Clandinin (1999) described curriculum-making as interwoven with identity-making, and as such, a rich contextual process that is imbued with individuals' 'stories to live by'.

\section{'Stories to live by' in the Professional knowledge landscape}

'Stories to live by' is a term that allows us to "understand how knowledge, context, and identity are linked and can be understood narratively” (Connelly \& Clandinin, 1999, p.4) and is thus a way to narratively conceptualize identity. Seeing identity narratively enables us to see it in the midst, that is as in the making and as shaped by past, present and future experiences in relation to places, and sociality. Thinking about 'stories to live by' as intertwined with curriculum-making allows us to inquire into Ashley's experience and to better understand how his ‘stories to live by' were shifted and shaped in his professional knowledge landscape (Clandinin \& Connelly, 1995).

Clandinin and Connelly (1995) use the notion of professional knowledge landscape as a narrative metaphor to show the narrative nature of school and out of school contexts. Like 'stories to live by', the professional knowledge landscape metaphor offers opportunities to inquire into the relational, temporal, and always shifting nature of school contexts. For example, as we began to inquire into Ashley's past, present and future 'stories to live by' we became aware of the complex nature of how curriculum came to be positioned for him in the professional knowledge landscape and the role that he played in the shifting of his 'stories to live by'. Inquiring into Ashley’s experiences, with a particular attention given to ‘stories to live by', we explore how his experiences of pedagogical and curricular change interact with the context of the 'professional knowledge landscape'. This 
juxtapositioning allowed us to pay greater attention to the 'bumping' that is often felt by physical educators as they negotiate how they are situated within a school setting (Casey, 2012; Schaefer \& Clandinin; 2011).

The purpose of this paper, therefore, is to show the processes of this narrative inquiry and to explore the bumping that surfaced for Ashley as his 'stories to live by' (Clandinin and Connelly, 1999) around physical education bumped hard with the dominant narratives of physical education on his professional knowledge landscape and led him to renegotiate, re-live, his own stories of pedagogical and curricula change.

\section{Method}

\section{Living, telling, re-telling, re-living,}

We began our conversations by thinking about Clandinin and Connelly’s (2000) notions of 'living, telling, re-telling, and re-living'. This is an integral part of the conceptual frame of the paper, as it adheres to narrative inquiry as phenomenon. We illustrate these concepts in this section to help us describe the methodological unfolding of this paper.

Living: each of us live stories, and live in stories. While we live in our own personal stories, we also live in institutional stories, cultural stories and other stories that shift and shape how we live.

Telling: each of us tell stories. We tell stories about ourselves, and again we tell stories about the institutions within which we work and the cultures within which we live.

Re-telling: while each of us live and tell stories we may not get the opportunity to re-tell our stories; to think deeply about the multiplicity of stories shaping our experiences, our 'stories to live by', and perhaps come to see our stories differently. 
This re-telling is what narrative inquirers refer to as the inquiry process into our stories of experience.

Re-living: This is the transactional nature of narrative inquiry. It is the notion that as we have the opportunity to think deeply about how our experiences are shaped by sociality, temporality and place (what Clandinin and Connelly (2000) called the three dimensions of metaphoric narrative inquiry space - see below) we, in turn, shape who we are and shift our future stories. "If we "change the stories we live by, quite possibly we change our lives” (Okri 1997, p. 46 as cited in Clandinin, 2013, p. 22).

Clandinin and Connelly (2000) explain that "the three dimensions of the metaphoric narrative inquiry space are: the personal and social (sociality) along one dimension; past, present and future (temporality) along a second dimension; situation place) along a third dimension.” Using these dimensions (i.e. sociality, temporality, and place) we find ways to inquire into Ashley’s lived experiences, and our own experiences during our inquiry to show how "the co-constructed experiences developed through the relational inquiry process” (Clandinin, 2006, p. 47).

It is important to note the significance of re-living that may be passed over too quickly, or seen as mundane, without particular attention. Dewey’s pragmatic ontology, and in turn narrative inquiry’s ontological commitments, are not transcendental but transactional. "The epistemological implications of this view are nothing short of revolutionary. It implies that the regulative ideal for inquiry is not to generate an exclusively faithful representation of a reality independent of the knower" (Clandinin \& Rosiek, 2007, p.39). This leaves the reader the opportunity to take up these findings in ways that are meaningful for them on their own knowledge landscapes and contexts. 
It is due to the transactional nature of narrative inquiry that we have deliberately tried to avoid the use of traditional signposts of academic writing such as results, discussion and conclusion. We have done this because the methodology of narrative inquiry is, by its very nature, "a walking into the midst of stories” (Clandinin, 2006, p. 47). In contrast to the narrative inquiry notion of entering into the midst of a story, traditional signposts infer fixed points of understanding and attempt to provide empirical realities outside of the participant's experience. This paper is presented in a way to allow each reader to enter and exit and interpret as they choose and "offer[s] readers a place [from which] to imagine their own uses and applications” (Clandinin \& Connelly, 2000, p. 42) of these ideas.

\section{The Authors}

More than a year before the writing of this paper began Ashley approached Lee to engage with 18 narratives that he had recently written following the re-reading of the extensive structured journaling he undertook during his masters and doctoral work (Casey, 2010). Given the call for this particular journal, Ashley approached Lee to engage in narrative research alongside the 18 narratives. Lee has worked extensively with narrative inquiry from Clandinin and Connelly’s (2000) perspective, and agreed to engage in the study. Given that the 18 narratives were written prior to this study, it offered a unique opportunity for Lee, prior to any inter-author conversations, to inquire into the narratives using the three dimensional narrative inquiry space. Notes were created on the margins that allowed for conversations to take place.

Through five one and a half to two hour voice recorded conversations, and a variety of other less formal conversations, Ashley and Lee inquired into their experiences using Ashley’s 18 narratives as field texts (data). So while the narrative 
fragments from the 18 narratives became a part of this paper, the narratives were also considered artefacts that allowed for a deeper inquiry into both Authors experiences. The first two conversations allowed Lee to ask questions about the 18 narratives that related to the three-dimensional narrative inquiry space. From these two conversations it became quite clear that there was much tension as Ashley attempted to negotiate his stories to live by on the professional knowledge landscape. Conversations three and four allowed us to inquire more deeply into the threads of tension to better understand how Ashley negotiated these experiences. Curriculum became a common thread within the tensions, and thus our final conversation focused on how Ashley began to conceptualize the curriculum in different ways. Given the scope of this paper, we focus on Ashley’s experiences and utilize narrative fragments from his initial 18 narratives. Through the inquiry we came to see shifting ‘stories to live by', curriculum as life-making, and a creation of counter stories to help negotiate the grand narratives surrounding physical education, and thus we chose narrative fragments that would help us to illustrate these particular concepts.

Just like all forms of research, some data are chosen while other data are tucked away. This was also the case in this particular study. As we inquired into our experiences we began to see bumping points, tensions perhaps, between Ashley’s 'stories to live by' and the stories of physical education on his professional knowledge landscape. While tensions can often be seen in a negative light, in this particular case, like other narrative inquirers (Cardinal, 2011; Huber, \& Keats, 2000; Schaefer 2013; Clandinin et al., 2014), we used these moments of tension as inquiry points, as moments within an experience where something 'bumped'. Throughout this inquiry we have wondered about other physical educators' 'stories to live by', their curriculum as life-making, their counter stories and the opportunities they might have 
to think about these things. Fundamentally we have thought about how narrative might offer Ashley and others ways forward in negotiating tensions between their stories to live by and the stories that live on their professional knowledge landscapes.

\section{Retelling Ashley's 'stories to live by'}

In the section that follows [what might traditionally be considered the results] we pay attention to the re-telling of Ashley's 'stories to live by' as they existed in the professional knowledge landscape of his school. We do this not in isolation, but in the understanding that his stories like "all representations are partial and involve tradeoffs between distortions and instrumental ends” (Clandinin and Rosiek, 2007, p. 37). From our own experiences as physical education teachers and teacher educators, we are cognisant of the dominant stories of physical education as a "subject in crisis" inasmuch as there is "considerable disparity between how physical education is practised” (Stolz \& Kirk, 2015, p. 1) in different schools and in different classrooms. We are acutely aware of the tensions within the institutional stories, cultural stories and broader stories surrounding physical education and do our utmost to articulate the interactional nature of these narratives.

In re-telling the stories that Ashley, his students, and his colleagues 'lived by' in their respective professional knowledge landscape we have tried to illuminate three threads we felt emerged most strongly: (a) bumping and tensions, (b) shifting stories alongside the dominant narrative, and (c) silent stories and counter stories. While these threads resonated with both Authors in the re-telling stage they might equally have been silenced in another's viewing of Ashley’s experiences. That said, these are the resonant threads we have sought to 'worry at' and unravel in an effort to better understand Ashley’s experiences.

\section{Bumping and Tensions}


I was an idiot or an idealist to try anything like this. Brainwashed by the ideas of ivory-tower dwelling intellects with no idea what actually happens in schools. Surely this is a step too far. Doing this with younger kids who don't know anything else is one thing, but getting kids already used to how things go to change seems like an idiot's quest. Step the idiot.

"I was an idiot." In thinking about sociality, the initial phase of the narrative fragment denotes a tension and self-doubt around the implementation of something outside of what the students expected in physical education. There is a sense that Ashley felt betrayed by the stories told in 'the ivory tower' about what physical education could be if only practitioners just better understood how to shift the curriculum. As Ashley brings his own stories and the stories of physical education from the university to the professional knowledge landscape, and as the theories fall foul of the realities of practice, it becomes clear that these two stories are not coherent and do not align.

From the fragment above we also denote a story of physical education being told by the students whom Ashley is attempting to teach. While there are certainly institutional stories of physical education and larger socio-cultural stories of physical education, in staying with Ashley's lived experiences we see that the students also carry with them stories of what physical education is, should be, and should not be. In shifting his own 'stories to live by' surrounding physical education, which in turns shifts his pedagogy and curriculum, it seems that Ashley is implicitly, and perhaps explicitly, asking the students to think differently and to shift their own stories of physical education. Thus in the shifting of Ashley's stories of physical education we see the students being brought along, 'kicking and screaming' it seems given his reaction, in this shifting.

School is a place that these kids dislike being anyway, well some of them, but at least when I'm being bossy they understand their place and their role. 
In conversations with Ashley during our re-telling, we came to understand the 'being bossy', and the yelling as a part of the stories of physical education that students expected, i.e. "the dominant, aggressive, not-to-bright individual, who is, within his [sic] own structure of rules, on relatively friendly terms with his pupils” (Whitehead \& Hendry, 1976, p. 75). Thinking temporally and moving back to our own experiences with physical education, we are reminded that the yelling and authoritative nature was also a part of the stories of physical education we were involved in. Indeed these stories almost certainly became a part of our own 'stories to live by', part of who we were/are as physical educators. Many would not be surprised by these stories, as it fits the traditional paradigm of teaching, particularly the physical educator, who historically would have been a drill sergeant set to turn young boys into masculine and fit young men (Bramham, 2010).

\section{Shifting stories alongside the grand narrative}

In the above section, thinking through the dimensions of place, temporality, sociality, and re-telling Ashley's experiences, we come to see that his classes were positioned as being familiar with stories of physical education as a place used to "harden you up and to help you be a better athlete” (Casey \& Quennerstedt, 2015). It is not therefore surprising that students responded more favourably to a more traditional, and perhaps, more expected stories of physical education. We might also add that while all students may not have adhered to these stories of physical education, it seemed to be the stories that counted in this place, and thus became acceptable stories for students to tell.

They (the students) were described by Ashley as the 'unteachables' and so of course it (Sport Education in this case) failed. In the re-telling, we also came to see 
that situating the students as deficit, as not understanding new stories of physical education, may have been a way of shifting the blame away from what Ashley saw as a failing intervention. In shifting the blame to the students, perhaps we fail to acknowledge the part that Ashley played in the perceived failure. This was not his first class at this school. In fact he had, in many ways, been adhering to the dominant stories of physical education for three years with these students prior to attempting to shift his own 'stories to live by'. Thus, in seeing the students as deficit, we lose the fact that Ashley changed the rules. Ashley had time within his own life and within his university courses to imagine otherwise (Greene, 1995) and to wonder about ways that physical education might be taught differently. The initial response from the students suggests that they had not had time, or an opportunity to experience anything other than the dominant stories of physical education.

Talk about a battle. Yet I get the feeling that some of the battle was with themselves [personally] and themselves [as classes]. I wouldn't say that it was a success as some lessons descended into a bit of a farce [which prompted Ian ${ }^{1}$ to question why I bothered] while others were really quite good [causing Ian some doubts that the traditional, teacher-led approach he had experienced and for which he often advocated, was the best way to teach].

While at the time Ashley may not have seen this 'battle' as a struggle for a story that made sense, through the re-telling process, and thinking temporally about the students' experiences, we see that just as Ashley bumped with the dominant stories of physical education, the students are bumping with a new story of physical education.

Moving away from the students, but drawing further on the story fragment above we see other grand narratives of physical education intermingling with

\footnotetext{
${ }^{1}$ Ian (a pseudonym) was a 19 year-old student who had been employed to work as a teaching assistant in the physical education department for one calendar year (2007). He brought with him his own 'stories to live by' with regards to physical education which, anecdotally, included elite sport and teacher-as-teller.
} 
Ashley's stories and the students' stories. In thinking about the stories we live within, we must also be attentive to not only the institutional stories of physical education, but also the collegial stories of physical education. Here we make a distinction between collegial stories of physical education and institutional stories of physical education.

In the story fragment above we wonder about how Ian’s stories, as collegial stories, fit into the larger institutional stories surrounding both physical education and Ashley. We see these stories, stories of colleagues and stories of how colleagues perceive Ashley, as being an important aspect of Ashley negotiating what we are calling a different story of physical education. Many of his physical education colleagues saw Ashley’s shifting practice as inappropriate. In fact, on one occasion when a new colleague wanted to observe Ashley teaching perhaps in a different way, the colleague was asked by the head of the girls' department why she would want to watch Ashley teach, as he “didn’t teach properly.” We are here again reminded of the collision between the dominant stories of physical education and Ashley's emerging 'stories to live by'.

In many ways these bumping stories run deeper than simple practice and ask philosophical questions about what counts, and should count, in physical education (Hellison, 2007). Which knowledge is important? How will students show they know this important knowledge? Who will the curriculum be created for and indeed, who will create it? In revisiting these stories (both in their initial telling and now in their re-telling) we see the complexities of multiple stories of physical education that seemingly do not fit coherently together.

Silent stories and counterstories 
It is important to think about not only how Ashley was situated within the professional knowledge landscape, but also how he may have storied his colleagues. For example, while some colleagues, like Ian, may have been politely contentious of Ashley's new stories of physical education and questioned why he would go to all the trouble, others were positioned as being unaccepting of change.

There is no other way, it seems, to learning how to 'do this' and it really isn't a case of doing it by the book, but a case of trial and error and coming up with my way of doing it. This is certainly my project, as Adam ${ }^{2}$ couldn't give a shit. In investing nothing in the project, beyond his 'trust' in me, and making little or no effort to learn what I'm doing and why I think it's important, then he places the responsibility squarely on me and my shoulders. This isolates me and makes this scrap of an idea even more important. My wider reading tells me that this teacher's article is just a starting point, but for me it is all I can understand as a teacher. I have no-one to talk to about this and the kids will get the best of what I can manage based on what I understand and focused on the clues that the article provides.

By unpacking this narrative we come to see that there is a counterstory being written (Lindeman Nelson, 1995). Clandinin et al. (2014) posited that dominant narratives can serve to silence or control particular groups by framing them as 'less than' or deficient. A counterstory then is a story that enables the orator to re-tell their stories and begin, in small ways, to undermine the dominant narrative. Although Ian may express the feeling that Ashley is spending too much time on this counterstory of physical education, we might also wonder whether Ian (as a colleague) is starting to challenge, and perhaps even re-tell, his own stories of physical education.

Building on this notion of counterstory, we could say that Ashley is composing a story in isolation, against the grain, and in many ways he seems to be bumping up against his colleagues’ stories. It becomes apparent that there is

\footnotetext{
${ }^{2}$ Adam (a pseudonym) was the Head of Boys' physical education whose part in the 'parade' predated and postdated Ashley's time at the school.
} 
something, in this particular case a magazine article ${ }^{3}$, helping to create a

counterstory. However, it also becomes apparent that this counterstory is in the midst, and written over a temporal span.

It would be easy to present Ashley’s narratives unproblematically and question the motives and professional integrity of colleagues such as Adam. Indeed, in Ashley's initial telling of his lived experiences that is what he appeared to do. Yet as our re-telling unfolded we began to wonder about Adam's stories. Imagine Adam's own isolation as a physical educator within a system that particularly devalues the epistemic status of physical education and greatly values the success of the sports teams he coaches. In thinking with Adam's stories we wonder about how difficult it must have been for Adam to be challenged by a new story of physical education, a story that from Ashley’s perspective, and perhaps the broader research perspective, was a better way to engage students in physical education. It becomes quite easy to imagine how difficult it would be for Adam to see his pedagogy, perhaps painfully constructed and developed over many years, being criticized by a younger colleague as well as the broader research field. Thinking with Adam's stories enables us to imagine how difficult it would be for Adam to participate in this counterstory.

While attending to the bumping between both Ashley’s and Adam's stories, we remain aware of the notion of counterstory, and how Ashley continued to shift his 'stories to live by’.

In the last four interventions, the kids often see the links that I've just missed, any of them seems to be able to do this and then they put it into a language that their peers understand. This is one of the things that so many teachers I know get wrong and yet when the expertise of the kids is used...even if it is just their innate ability to be an 11 or 12 year old kid [which they are] and translate my

\footnotetext{
${ }^{3}$ This article (Kinchin, 2002), written for teachers by a teacher educator, was the first such article that Ashley found that explained the new approaches to teaching he was using in a non-academic language. It was helping him to try and create one story in his classroom while Adam, he felt, was clinging to another.
} 
written and verbal instructions and guidance into a language that those who don't get it can get it. This seems a vital ingredient in the success of these units.

In the re-telling of the fragment above, we also came to wonder about Ashley's initial positioning of his new 'stories to live by' as interventions. How does this situate the students if Ashley sees himself as the interventionist? The term intervention, often used in psychological work, deems that someone is the expert and knows what interventions are needed to fix the 'other' up. Yet as the fragment moves forward, we see that the students may have become interventionists for Ashley’s stories, and thus a co-composition is/was in the midst. In elevating the "expertise of the kids" we see that Ashley no longer deemed the students as deficit but instead saw them positively responding to the fact that he changed the rules. It gives the sense that Ashley and the students were making something up, in a relational way, that made sense to them within the knowledge landscape. From the perspective of this paper it could be seen as an initially orchestrated attempt by Ashley to shift his students from the dominant stories of physical education as a "subject in crisis" (Stolz \& Kirk, 2015, p. 1) to a cocomposition of 'healthier' stories of physical education through and by which he and they could live by.

Being aware to this co-composition allows us to see that we must be both careful and cognisant of the "multiple curricula being composed” (Huber et al. 2011, p.6), often simultaneously, in a single classroom or gymnasium. To this end, and as we seek to summarise this paper, we move back to the beginning and think about the implications of the living, telling, and re-telling on the re-living. Within this re-living, we are aware of both the multiple stories and curricula at work throughout Ashley’s shifting 'stories to live by'. Particularly we are attentive to how these multiple stories 
in many ways help to shape multiple curricula that, when engaged with, might allow for individuals to engage more deeply with their own 'stories to live by'.

\section{Re-living}

The narratives of Ashley’s lived experiences, i.e. his autobiography, are one of the starting points of narrative inquiry. Such an inquiry, in narrative terms, helps us to position and conceptualise Ashley's story and as such allows us to examine his storied experiences and situate them in a place and in time. While the initial telling of the story is important, it is more important to re-tell and inquire into the story in a manner that allows for change and growth (Clandinin \& Connelly, 2000). The telling of the story is, in itself, a way of framing our past experiences from our current standpoint. From there it allows us to move forwards and backwards between the story and the restorying and between the personal and the social. "These narrative beginnings of our own livings, tellings, re-tellings and re-livings help us deal with questions of who we are in the field and who we are in the texts we write in our experience” (Clandinin \& Connelly, 2000, p. 70). These stories - past or present, personal or social - are not external to participants' experiences, but are lived in some way by everyone who comes in contact with them. We live out these stories and, in their re-living and retelling, "generate a new relation between a human being and her environment - her life, community, world - one that makes possible a new way of dealing with them, and thus eventually creates a new kind of experienced objects, not more real than those which preceded, but more significant and less overwhelming and oppressive” (Clandinin \& Rosiek, 2007).

The inquiries into Ashley's experiences have formed the resonant threads of our narrative inquiry. Throughout we 'worried at' and sought to unravel these narratives in an effort to better understand the "multiple curricula being composed" 
(Huber et al. 2011, p.6) in this local context, a single school; and through the narratives of one teacher.

[...] ]our transformative pedagogies must relate both to existing conditions and to something we are trying to bring into being, something that goes beyond the present situation.

(Greene, 1995, p. 7)

Greene’s words call attention to the ever-shifting notion of lives that are always in the midst. In moving beyond the present situation, Greene reminds us that there must be an imagined otherwise in mind if we are to transform our conditions. A question we might ask of physical education teachers and perhaps researchers is what life events, experiences, might shift a teacher’s stories to live by around physical education?

\section{Imagining new stories of physical education curriculum}

In the case of Ashley, his graduate work became a pivotal point in which he began to imagine new 'stories to live by' as a physical educator. As we engaged in this narrative inquiry and inquired into Ashley's stories of what could be seen as transformative pedagogy, we became aware of the notion that there was indeed an imagined story of physical education that moved beyond Ashley's present situation. There was a tension between the stories of physical education he was living out and the grand narratives that this living bumped against. It would have been quite easy, and would have created less tension, if Ashley continued to live the dominant stories of physical education. Yet as his ‘stories to live by’ shifted, the professional knowledge landscape that had once seemed so familiar began to make less and less sense to him. 
We have come to conceptualize this 'making sense' as narrative coherence. For Carr (1986) narrative "coherence seems to be a need imposed on us whether we seek it or not” (p. 97), and that need for coherence is a constant struggle as we try to make sense of our stories. "What we are doing is telling and re-telling, to ourselves and to others, the story of what we are about and what we are” (p. 97). In this searching for narrative coherence there is a continuous process underway in which "we are composing and constantly revising our autobiographies as we go along” (p. 76). Thinking of this process as an individual struggle is one way to think about how we may come to make sense of our lives. Yet Carr helps us to see the cultural, social, institutional and familial narratives that we live within as we revise who we are in relation to these multiple narratives.

In paying particular attention to the narrative fragments shared, and inquired into in this paper, we see moments of “autobiographical revision” (Carr, 1986, p. 76) that move Ashley closer to what seems to be narrative coherence. His 'stories to live by', his identity, the stories of what he was and was about, situated not only himself differently in the professional knowledge landscape, but also situated the students, his colleagues, and the dominant stories of physical education differently.

\section{Living curriculum}

Another question we might ask then is how does a curriculum become lived as opposed to implemented? In Ashley's case we see the curriculum as becoming lived because it happened in relation and not isolation. Drawing on the work of Greene (1997), Enright and O’Sullivan (2012) concluded, “we cannot make significant change on our own. We need to ‘move newcomers’ (Greene, 1997, p. 10) to join with us and transform”. As we explore Ashley’s shifting relationship with curriculum and the students we see that they were, at first, 'left out in the cold' as he shifted his 
'stories to live by’. As Ashley’s narratives unfolded, however, it became evident that he began to see the students as his chosen community (Lindeman-Nelson, 1995) and, like the students in Enright and O’Sullivan's (2012) study, they became a part of the change and therefore part of a sustainable story of physical education that they cocreated. In doing this, the students became knowledge holders, and as Ashley pointed out, were often able to use their own language to describe what he could not. It seems that Ashley’s autobiographical revisions included a shift away from him as curriculum implementer/interventionist, to the students and himself as curriculum planners.

Positioning 'a' curriculum in isolation from teachers and students lives replicates the notion that others (researchers, administrators and governments) know what is best for both teachers and students. Yet as we pay careful attention to the implications of this particular paper, we see that 'a' teacher alongside students in a particular context was able to co-compose curriculum that made sense to both him and, eventually, some of his students. Like Huber el al. (2011, p. 6) we come to see that there are indeed "multiple curricula being composed" in relation to both the students and the teachers and alongside both institutional stories and dominant stories of physical education. We see this process as interwoven with identity-making and, as such, a rich contextual process that is imbued with individuals' 'stories to live by' (Clandinin, 1995). We also see this process as a re-living and changing of stories. "If we 'change the stories we live by, quite possibly we change our lives'” (Okri 1997, p. 46 as cited in Clandinin, 2013, p. 22), and possibly those lives around us.

\section{Living in coherent ways}

While it is one thing to shift our 'stories to live by', it is another to be able to live in coherent ways on a professional knowledge landscape that has stories which 
are not so easily shifted. Consequently we are left to ponder how the work of this paper positions us (and perhaps PETE educators) to move forwards. As PETE educators and researchers, how might we support future PE teachers in ways that help them negotiate their own 'stories to live by' in complex professional knowledge landscapes? We find ourselves constantly teaching, telling, modelling different ways to think about physical education, ways that often bump with the dominant stories of physical education. When students come back after field placements they often speak to how disconnected their experiences were as they entered into what their mentors often call the 'real world'. We reassure them that what we are teaching here, at the university, works you just have to keep at it; keep learning, don't succumb to the professional socialization that often de-professionalises physical education (Rossi et al. 2015).

Are we, as PETE educators, the wolf in sheep’s clothing? What knowledge or skills to do we provide future PE teachers with in order to negotiate these contested landscapes? Perhaps pedagogically and subject area wise they are well prepared, but what knowledge is needed to be sustained as a physical education teacher who, like Ashley, is interested in shifting the dominant stories of physical education? How do we support them as they move into their first years of teaching? How do we help them to negotiate the dominant story of physical education and their own shifting identities and living as a person who teaches? We do not have the answers to these questions but suggest that Ashley’s experiences help us, and hopefully other PETE educators, to think more deeply about the stories we are helping to construct in PETE programmes and what prospective physical education teachers are left to do as they negotiate these stories, their own 'stories to live by', and the dominant stories of physical education that live in professional knowledge landscapes. 
Acknowledgements: We would like to thank Jean Clandinin, Victoria Goodyear, Tim Fletcher, Doug Gleddie, Lesley Casey, and Julia Sargent who all help us to engage in and with the re-telling and re-living of this narrative inquiry.

\section{References}

Armour, K.R. \& Jones, R.L. (1998). Physical education teachers’ lives and careers. London: Macmillan

Bramham, P. (2010). Boys, Masculinities and PE. Sport Education and Society, 8(1), $57-71$.

Cardinal, T. (2011). Stepping stone or saving story? LEARNing Landscapes, 4 (2), 7991.

Carr, D. (1986). Time Narrative and History. Indiana: Indiana University Press.

Casey, A. (2010). Practitioner research in physical education: Teacher transformation through pedagogical and curricular change, Unpublished Doctoral Thesis, Leeds Metropolitan University.

Casey, A. (2012). A self-study using action research: changing site expectations and practice stereotypes, Educational Action Research, 20 (2), 219-232. DOI: 10.1080/09650792.2012.676287

Casey, A. \& Quennerstedt, M. (2015): “I just remember rugby”: Re-membering Physical Education as More Than a Sport, Research Quarterly for Exercise and Sport, Volume 86 (1), 40-50 DOI: 10.1080/02701367.2014.977430

Clandinin, D.J. (1995). Stories of possibility: Living on the landscape with children. Early Childhood Education, 28 (2), 4-8. 
Clandinin, D. J. (2006) Narrative Inquiry: A methodology for studying lived experience. Research Studies in Music Education, 27, 44-54.

Clandinin, D.J. (2013). Engaging in narrative inquiry. Walnut Creek: Left Coast Press

Clandinin, D.J., \& Connelly, F.M. (1988). Teachers as curriculum planners: Narratives of experience. New York, NY: Teachers College Press.

Clandinin, D.J., \& Connelly, F.M. (1995). Teachers' professional knowledge landscapes. New York: Teachers College Press.

Clandinin, D.J., \& Connelly, F.M. (1996). Teachers’ professional knowledge landscapes: Teacher stories, stories of teachers, school stories, stories of school. Educational Researcher, 25 (3), 24-30.

Clandinin, D.J., \& Connelly, F.M. (1998). Personal experience methods. In N. K. Denzin \&Y. S. Lincoln (Eds.) Collecting and Interpreting Qualitative Materials (pp. 150-178). Thousand Oaks, CA: Sage.

Clandinin, D.J., \& Connelly, F.M. (1999). Storying and restorying ourselves: Narrative and reflection. In A. Y. Chen \& J. Van Maanen (Eds.), The reflective spin: Case studies of teachers in higher education transforming action (pp. 15-23). Singapore: World Scientific.

Clandinin, D.J., \& Connelly, F.M. (2000). Narrative Inquiry: Experience and story in qualitative research. San Francisco: Jossey-Bass.

Clandinin, D. J. \& Rosiek, J. (2007). Mapping a landscape of narrative inquiry: borderland spaces and tensions, (pp. 35 - 75) in D. J. Clandinin (Ed.) Handbook of narrative inquiry: Mapping a methodology. London: Sage. 
Clandinin, D.J., Schaefer, L., \& Downey, A. (2014). Narrative conceptions of knowledge: Towards understanding teacher attrition. Bingley: Emerald Group Publishing.

Connelly, F., \& Clandinin, D. J. (1994). Telling teaching stories. Teacher Education Quarterly, 21(1), 145-158.

Connelly, F. M., \& Clandinin, D. J. (1999). Storied identities: Storied landscapes. New York: Teachers College Press.

Darling-Hammond, L. (2010). Teacher education and the American future. Journal of Teacher Education, 61:35-47.

Dewey, J. (1938). Experience and education. New York: Collier Books.

Dewey, J. (1958). Nature and experience. New York: Dover

Dowling, F. Garrett, R. Hunter, L. \& Wrench, A. (2013) Narrative inquiry in physical education research: The story so far and its future promise. Sport Education and Society, iFirst, DOI:10.1080/13573322.2013.857301 Retrieved from http://www.tandfonline.com/doi/full/10.1080/13573322.2013.857301

Enright, E. \& O'Sullivan, M. (2012). Physical Education “in All Sorts of Corners”, Research Quarterly for Exercise and Sport, 83:2, 255-267, DOI: 10.1080/02701367.2012.10599856

Geertz, C. (1995). After the fact: two countries, four decades, one anthropologist. Cambridge, Mass: Harvard University Press.

Greene, M. (1995). Releasing the imagination: Essays on education the arts, and Social Change. San Francisco: Jossey Bass.

Hellison, D. (2007). Teaching personal and social responsibility through physical activity. Leeds, UK: Human Kinetics. 
Huber, J., \& Keats, W.K. (2000). Stories within and between selves: Identities in relation on the professional knowledge landscape. Unpublished doctoral dissertation, University of Alberta, Edmonton, Canada.

Huber, J., Murphy, S., \& Clandinin, D.J. (2011). Places of curriculum making: Narrative inquiries into children's lives in motion. Bingley, UK: Emerald Group Publishing.

Kirk, D. \& Macdonald, D. (2001). Teacher voice and ownership of curriculum change. Journal of Curriculum Studies, 8(2), 271 -298

Lindeman-Nelson, H. (1995). Resistance and insubordination. Hypatia: A Journal of Feminist Philosophy, 10(2), 23-40.

Macdonald, D. (2003). Curriculum change and the post-modern world: is the school curriculum-reform movement an anachronism? Journal of Curriculum Studies, 35, 139-149.

McCaughtry, N. (2004). The emotional dimension of a teachers's pedagogical content knowledge: Influences on content, curriculum and pedagogy. Journal of Teaching in Physical Education, 23,30 -47

O’Sullivan, M (1994). High school physical education teachers: Their world of work. Journal of Teaching in Physical Education, 13(4), 323-441.

Rossi, T., lisahunter, Christensen, E., \& Macdonald, D. (2015). Workplace Learning in Physical Education: Emerging stories from the staffroom and beyond. London: Routledge.

Rovegno, I., Chen, W. \& Todorovick, J. (2003). Accomplished teachers’ pedagogical content knowledge of teaching dribbling to third grade children. Journal of Teaching in Physical Education, 22, 426-449. 
Schaefer, L. (2013a). Beginning teacher attrition: a question of identity making and identity shifting. Teachers and Teaching: Theory and Practice, 19(3), 260274.

Schaefer, L. (2013b). Narrative inquiry for physical education pedagogy. International Journal of Pedagogies and Learning, 8(1), 18-26

Schaefer, L. \& Clandinin, D. J. (2011) Stories of sustaining: A narrative inquiry into the experiences of two beginning teachers. Learning Landscapes, 4 (2), 275295.

Stolz, S.A. \& Kirk, D. (2015). David Kirk on physical education and sport pedagogy: in dialogue with Steven Stolz (part 1), Asia-Pacific Journal of Health, Sport and Physical Education, DOI: 10.1080/18377122.2014.997862

Tsangardou, N. \& O’Sullivan, M. (1997). The role of reflection in shaping physical education teachers’ educational values and practices. Journal of Teaching in Physical Education, 17, 2-25.

Tsangardou, N. \& O’Sullivan, M. (2003). Physical education teachers theories of action and theories-in-use. Journal of Teaching in Physical Education, 22, 132-152.

Whitehead, N. \& Hendry, L.B. (1976). Teaching physical education in England: Description and analysis. London, UK. Lepus Books. 